Ilmu Pertanian (Agricultural Science)

Vol. 3 No. 2 August, 2018: 82-89

Available online at http://journal.ugm.ac.id/jip

DOI: doi.org/10.22146/ipas.37495

\title{
Biochemical Changes Of Three Cocoa Clones (Theobroma cacao L.) Under Drought Stress
}

\author{
Fakhrusy Zakariyya ${ }^{1 *}$, and Didik Indradewa ${ }^{2}$ \\ ${ }^{1}$ Pusat Penelitian Kopi dan Kakao Indonesia \\ ${ }^{2}$ Faculty of Agriculture, Gadjah Mada University, Bulaksumur, Yogyakarta, Indonesia \\ *Corresponding email:fakhrusy.zakariyya@gmail.com
}

\begin{abstract}
Drought stress is a serious threat for cocoa production. One of the plant mechanisms to survive from the drought stress is through producing some biochemical compounds. The objective of this research was to know biochemical changes in three cocoa clones during drought stress. The research was conducted at the green house of Indonesian Coffee and Cocoa Research Institute from January-December 2017. The experiment was designed by using Randomized Complete Block Design (RCBD) with 2 factors and with 3 replications. The first factor was clones of scion that consisting KW 641, Sulawesi 1 and ICS 60 which each of its grafted to Scavina 6 clone as rootstock. The second factor was watering intervals which consisting; every 2 days/regularly watering (adequate of water), every 5 days (moderate drought), and every 8 days (severe drought). The result of this research showed that drought stress decreased chlorophyll content, increased hydrogen peroxide content, increased the activity of superoxide dismutation (SOD), increased ascorbic acid content, increased total phenolic content, and increased proline content. Sulawesi 1 and KW 641 clones showed lower hydrogen peroxide content, while chlorophyll content, SOD activity, total phenolic content, ascorbic acid content, and proline content were higher compared with ICS 60 clone. It showed that Sulawesi 1 and KW 641 clones had more drought-resistance compared with ICS 60 clone.
\end{abstract}

Keywords: Antioxidant, Chlorophyll, Clone, Drought Stress, ROS.

\section{INTRODUCTION}

Cocoa is a plantation commodity that has high economic value. Currently, Indonesia had been the third biggest producer of cocoa in the world following Ivory Coast and Ghana with production capacity about 320 thousand tons/year (ICCO, 2017). In other hand, the production of cocoa can be potentially decreased due to drought stress that related to climate change. The phenomenon of ENSO (El Nino Southern Oscillation) had an effect of a longer dry season on last several years in Indonesia and could reduce cocoa production up to $30 \%$ and even death of plants (Soertani \& Soenardjan, 1984; ICCO, 2010; Sakiroh et al, 2015). Almeida \& Valle (2010) reported that drought stress negatively affected on the growth of cacao plants.

The drought stress generally caused an imbalance of the redox reaction in cells (Maheswari and Dubey, 2009) and followed by oxidative stress that inducing overproduction of reactive oxygen species (ROS), such as superoxide ion $\left(\mathrm{O}_{2}{ }^{-}\right)$, hydrogen peroxide $\left(\mathrm{H}_{2} \mathrm{O}_{2}\right)$ and hydroxyl radicals $\left(\mathrm{OH}^{-}\right)$. ROS damage vital cellular components, such as membrane cell, protein, nucleic acid (Maheswari \& Dubey, 2009). Moreover, the presence of ROS will damage the chlorophyll pigment and then inhibit the photosynthesis and other physiological processes (Sade et al., 2011).

In order to survive, cocoa plants respond this condition by producing and accumulating biochemical compounds to protect plant cell from ROS (Alban et al., 2015). Zaneti et al. (2016) stated that cocoa possess a mechanism to reduce ROS by producing and activating antioxidant compound. The antioxidant compounds that produced can be either from the enzymatic or non-enzymatic group. Antioxidant acts by donating one electron to ROS, metal ion chelation, co-antioxidants, play role on gene expression, and inhibit cellular damage through their scavenging 
property (Ahmad et al., 2010).

Alban et al. (2016) reported that enzymatic antioxidant in cocoa that involved in counteracting free radicals include superoxide dismutase (SOD), catalase (CAT), and peroxidase (POX). Santos et al. (2014) also showed an increase guaiacol peroxidase (GPX) as an antioxidant metabolism. SOD react with free radicals as superoxide scavenger to produce hydrogen peroxide $\left(\mathrm{H}_{2} \mathrm{O}_{2}\right)$. Catalase and glutathione peroxidase enzymes reduce $\mathrm{H}_{2} \mathrm{O}_{2}$ become $\mathrm{H}_{2} \mathrm{O}$. Each of these enzymes works with a feedback system.

Non-enzymatic antioxidant or commonly known as secondary antioxidant in the plant are generally from phenolic compounds that can be group of flavonoids, cinnamic acid derivatives, coumarin, tocopherol, and polyfunctional organic acids (Sulistyani et al., 2011). Ascorbic acid is one of antioxidant that can reduce ROS directly and also a substrate for the antioxidant enzyme, such as Ascorbate peroxidase (APx), that is important in stress resistance. Zanneti et al. (2016) indicated that polyphenols are widely produced by the cocoa plant as antioxidant to overcome water stress. Another non-enzymatic antioxidant that potentially to prevent ROS is proline (Shevyakova et al., 2009), even though proline also known as a compound that play a role in osmotic adjustment. Under drought stress, Zakariyya et al. (2016) showed that there were increasing of proline in resistant cocoa clones. Changes in these biochemical compound on cocoa grafted seedling were still relatively limited to be studied. Alban et al. (2016) stated that antioxidant activity could be a promising way for the early selection of cocoa genotypes tolerant to drought stress. The objective of this research was to identify biochemical changes on three different cocoa clones leaf under drought stress.

\section{MATERIALS AND METHODS}

The experiment was designed by using Randomized Complete Block Design (RCBD) with 2 factors. The first factor was clones of scion material that consisting KW 641, Sulawesi 1 and ICS 60 which each of its grafted to Scavina 6 as rootstock. Furthermore, KW 641 was indicated as drought tolerant clone (Susilo et al., 2015; Zakariyya et al., 2017) and ICS 60 was indicated as drought succeptible clone (Winaryo et $a l .$, 1997). The second factor was watering interval which consisting every 2 days / reguraly watering (adequate), 5 days (moderate drought), and 8 days (severe drought).

The experiment was conducted at the greenhouse of Indonesian Coffee and Cocoa Research Institute, Jember, East Java. The activity of SOD, hydrogen peroxide content, polyphenol, and ascorbic acid was analyzed in Soil Laboratory of Indonesian Coffee and Cocoa Research Institute, Jember, East Java. The observation of proline and total chlorophyll content was tested in Crop Production Management Laboratory, University of Gadjah Mada, Sleman Regency, Daerah Istimewa Yogyakarta. This research was conducted in January-December 2017.

Total chlorophyll content was observed by spektofometric method within 80th day after treatment. Amount $0,1 \mathrm{~g}$ of fresh weight of leaf was pulverized with mortar then extracted with $50 \mathrm{ml}$ acetone $80 \%$ and filtered with filter paper using a funnel in erlenmeyer glass. After the extract obtained, acetone $80 \%$ was added until $50 \mathrm{ml}$. The extract was put into the cuvette to measure its absorbance with Spectrophotometer Varian CARY 50 CONC at the wavelength $663 \mathrm{~nm}$ and $646 \mathrm{~nm}$. Chlorophyll was calculated as follows: Chlorophyll Total $=20.2($ A 645) $+2.02($ A 663) .

Hydrogen peroxyde $\left(\mathrm{H}_{2} \mathrm{O}_{2}\right)$ content was observed refer to a method that developed by Alexieva et al. (2001). Amount $0.5 \mathrm{~g}$ of fresh leaves were crushed then put into a test tube and added with $5 \mathrm{~mL} 0.1 \%$ $(\mathrm{w} / \mathrm{v})$ trichloroacetic acid (TCA) for homogenization. $0.5 \mathrm{ml}$ of supernatant was taken and put into a test tube and added with $0.5 \mathrm{~mL} 100 \mathrm{~mm}$ potassium phosphate buffer and $2 \mathrm{~mL}$ reagent potassium iodide ( $1 \mathrm{M} \mathrm{KI} \mathrm{w} / \mathrm{v}$ in $\mathrm{H}_{2} \mathrm{O}$ ). Then, it was incubated for 1 hour in dark condition. $\mathrm{H}_{2} \mathrm{O}_{2}$ content was measured by using spectrophotometer UV-VIS (PerkinElmer, USA) at wavelength $390 \mathrm{~nm}$. The blank was $1 \%$ TCA in the absence of cocoa leaf extract. The $\mathrm{H}_{2} \mathrm{O}_{2}$ content was calculated using the equation of $\mathrm{H}_{2} \mathrm{O}_{2}$ standard curve that already known its concentration. Standard curve was determined through the preparation of pure $\mathrm{H}_{2} \mathrm{O}_{2}$ in various concentrations. $\mathrm{H}_{2} \mathrm{O}_{2} 1000$ ppm stock solution was prepared then diluted to several concentrations and read its absorbance using spectrophotometer at $390 \mathrm{~nm}$ wavelength.

The SOD test was performed based on the method that developed by Marklund and Marklund (1974), and its activity was tested by autoxidation pyrogallol method. Briefly, $50 \mathrm{mM}$ Tris- $\mathrm{HCl}$ buffer $\mathrm{pH} 8.2$ with $1 \mathrm{mM}$ EDTA was used as reaction medium then added with $40-60 \mathrm{mg}$ sample of protein extract and mixed $100 \mu 10.2 \mathrm{mM}$ pyrogallol (dissolved in $50 \mathrm{mM} \mathrm{PPB} \mathrm{pH} \mathrm{6.5)} \mathrm{to} \mathrm{start} \mathrm{the} \mathrm{reaction,} \mathrm{and} \mathrm{the}$ decreasing of pyrogallol absorbance was measured at $420 \mathrm{~nm}$.

Total phenolic content was observed using visible 
spectrometry method following Taga et al. (1984) procedure. Material such plant organ was mixed in $70 \%$ solution of methanol with ratio 1: 6 and mashed it with mortar. The extract that already obtained was incubated for 24 hours in $4{ }^{\circ} \mathrm{C}$. After 24 hours, the extract was centrifuged at $10,000 \mathrm{rpm}$ for 10 minutes. A $5 \mu \mathrm{L}$ supernatant were dissolved in $45 \mu \mathrm{L}$ of Methanol, $1 \mathrm{~mL} 2 \% \mathrm{Na}_{2} \mathrm{CO}_{3}$, and $50 \mu \mathrm{L} 50 \%$ Folin ciocalteu. The mixture of it needs to be shaked by using vortex and incubated for 30 minutes. Then it was poured into cuvette to read its absorbance in 750 $\mathrm{nm}$ wavelength using a spectrophotometer.

The ascorbic acid was tested using titration method refer to Sudarmadji et al. (1981). 20 grams of leaf was mashed then poured it into the flask. Aquadest was added to the flask until it reaches 100 $\mathrm{ml}$ and separated of its filtrated using filter paper. 5 $\mathrm{mL}$ filtrated was taken and incorporated into $125 \mathrm{~mL}$ Erlenmeyer and added with $2 \mathrm{~mL} \mathrm{1 \%}$ amylum solution. Then solution was titrated in iodine standard $0.01 \mathrm{~N}$ until solution change into blue. The calculation of 1 $\mathrm{mL}$ iodine 0.01 is equals with 0.88 ascorbic acid.

Proline content was analyzed refer to Bates (1973) method. 0.5 g leaves were crushed with mortar then mixed with $10 \mathrm{ml}$ sulfosalicylic acid 3\% then filtered with filter paper. $2 \mathrm{~mL}$ filtrate was taken and mixed with $2 \mathrm{~mL}$ ninhydrin acid and $2 \mathrm{~mL}$ glacial acetic acid into test tube and heated to $100^{\circ} \mathrm{C}$ for an hour. The reaction was terminated with inserting test tube into glasses that containing ice. The solution was extracted with $4 \mathrm{~mL}$ toluene, then it shook by using vortex for 15-20 seconds until formed 2 layers. The top layer that had red color which contains proline was taken using pipette then measured its absorbance with spectrophotometer with $520 \mathrm{~nm}$ wavelength. The proline content was determined based on the result of pure proline standard solution. The creation of ninhydrin acid was $1.25 \mathrm{~g}$ ninhydrin added with $30 \mathrm{~mL}$ glacial acetic acid and $20 \mathrm{~mL}$ phosphoric acid $6 \mathrm{M}\left(\mathrm{H}_{3} \mathrm{PO}_{4}\right)$ then heated until it dissolved. The proline content $\left(\mu \mathrm{mol} \mathrm{g}^{-1}\right)$ was calculated using formulation $64.3649 \mathrm{x}$ absorbance reading + $(-5.2987) \times 0.347$. The method to make ninhydrin acid was $1 \mathrm{~g}$ ninhydrin added with $24 \mathrm{~mL}$ glacial acetic acid and heated until changes into blue. A 2.5 $\mathrm{ml}$ phosphoric acid added with $5.5 \mathrm{~mL}$ aquadest then poured into ninhydrin solution and heated until it dissolved. The observation of $\mathrm{ROS} \mathrm{H}_{2} \mathrm{O}_{2}$, SOD activity, ascorbic acid content, total phenolic content and proline content were performed on 80 days after treatment. Data was analyzed by using analysis of variant (ANOVA) with $\alpha=5 \%$. If the result of variance analysis was obtained that $\mathrm{F}$ test $>\mathrm{F}$ table means there was significant difference between treatments, then continued with Tukey test with $\alpha=5 \%$ (Gomez \& Gomez, 1995).

\section{RESULTS AND DISCUSSION}

Based on this research results, analysis of variance showed that there were interactions between clone and watering interval on phenolic and proline content. Meanwhile, the single factor of clone affected on total chlorophyll, hydrogen peroxide content, superoxide dismutase activity, and ascorbic acid content. The single factor of watering interval also affected on total chlorophyll, hydrogen peroxide content, superoxide dismutase activity, and ascorbic acid content. The results were demonstrated in Table 1.

The response of three cocoa clones in drought stress showed various result. Common symptom that indicating cocoa suffered from water stress was leaf chlorosis. Chlorosis is an abnormally yellow color of plant tissues because less chlorophyll content. The decrease of chlorophyll content in cocoa could be attributed to the negative efects of water stress. Table 2. demonstrated that each watering interval and clone treatment affected to total chlorophyll content. Total chlorophyll content extremely decreased at the condition of severe drought stress (watering every 8 days) compared with the condition of ade-

Table 1. Analisis of Variance of Total Chlorophyll, Hydrogen Peroxide Content, Ascorbic Acid Content, Phenolic Total Content, and Proline Content as Affected by Clone and Watering Interval and their interaction

\begin{tabular}{lccc}
\hline Variables & Clone & Watering Interval & Interactions \\
\hline Total Chlorophyll & $3.76 *$ & $20.83 * *$ & $0.96 \mathrm{~ns}$ \\
Hydrogen Peroxide Content & $8.87 * *$ & $6.75 * *$ & $1.73 \mathrm{~ns}$ \\
Superoxide Dismutase Activity & $4.09 *$ & $16.97 * *$ & $0.89 \mathrm{~ns}$ \\
Ascorbic Acid Content & $6.72 * *$ & $11.10 * *$ & $2.28 \mathrm{~ns}$ \\
Phenolic total content & $6.15 * *$ & $21.99 * *$ & $3.06 *$ \\
Proline content & $8.59 * *$ & $58.32 * *$ & $3.68 *$ \\
\hline
\end{tabular}

Note : $*$ significant at $\alpha=5 \%$; $*$ significant at $\alpha=1 \%$; ns $=$ not significant 
Table 2. Total Chlorophyll $\left(\mathrm{mg} \mathrm{g}^{-1}\right)$ in Three Scion Clones Material and Different Watering Interval

\begin{tabular}{lcccc}
\hline \multirow{2}{*}{ Clones } & \multicolumn{3}{c}{ Watering Intervals } & \multirow{2}{*}{ Mean } \\
\cline { 2 - 4 } & Two Days & Five Days & Eight Days & $24.18 \mathrm{~b}$ \\
ICS 60 & 36.43 & 21.37 & 12.92 & $31.59 \mathrm{a}$ \\
KW 641 & 37.52 & 36.81 & 20.72 & $30.37 \mathrm{a}$ \\
Sulawesi 1 & 38.22 & 34.15 & 18.44 & $(-)$ \\
\hline Mean & $37.39 \mathrm{a}$ & $30.77 \mathrm{a}$ & $17.36 \mathrm{~b}$ & \\
\hline
\end{tabular}

Note : Data in the column or row followed by the same letters were not significantly different according to Tukey $5 \%$; Notation (-) shown there was no interaction between each factor.

quate soil water (watering every 2 days) and moderate drought stress (watering every 5 days). In average, the content of total chlorophyll in severe drought stress condition was $53.37 \%$ lower than normal condition. Rezaei- Chiyaneh et al. (2018) reported that increase in drought stress severity significantly decreased chlorophyll content.

Table 2 also showed that ICS 60 had lower chlorophyll content compared with KW 541 and Sulawesi 1. This result was similar to Prihastanti (2010), which cocoa seedling that exposed to drought stress for 1 month would significantly decrease in total chlorophyll content. Bae et al. (2008) stated that the duration of water limitation significantly decrease the efficiency of fluorescence absorption in chlorophyll. It was implied on declining photoshynthesis capacity on cocoa seedling. Commonly, decrease in photosynthesis rate, increase in respiration, and cell membrane leakage are known as the main results of water deficit stress in higher plants (Rezaei-Chiyaneh et al., 2018).

The degradation of chlorophyll during drought stress may result from photooxidative damage caused by the accumulation of reactive oxygen species (ROS) (Foyer, 2002; Cheour et al., 2014). Toxic hydrogen peroxide is one kind of ROS that generated from superoxide anion dismutation spontaneously or through enzymatic process. Ming-Yi et al. (1994) and Saglam et al. (2011) reported that chlorophyll degradation was accompanied by the increasing of $\mathrm{H}_{2} \mathrm{O}_{2}$ content. $\mathrm{H}_{2} \mathrm{O}_{2}$ increased lipid peroxidation, decreased the membrane stability, and ultimately accelerating leaf senescence (Upadhyaya et al., 2007). In other hand, the increased production of ROS during drought stress also can be considered as a celullar indicator of stress level (Ahmad \& Prasad, 2011). It means that the higher of ROS content, the more severe of stress level, especially drought.

Table 3 demonstrated that there was no significant interaction of watering interval and different clones to the hydrogen peroxide content. Meanwhile, single factor of watering intervals and clones had a significant effect to this variable, respectively. The longer watering interval, the higher of hydrogen peroxide content. Table 2 also showed both scion clone materials, KW 641 and Sulawesi 1 , were relatively resistant to drought compared with ICS 60 scion clone material, which generated lower hydrogen peroxide.

Hydrogen peroxide is generated in plants via dismutation of superoxide by SOD and via oxidases such as amino and oxalate oxidases (Jajic et al., 2015). $\mathrm{H}_{2} \mathrm{O}_{2}$ can also serve as a radical initiator such as decomposition of hydrogen peroxide to be hydroxil radical via the fenton reaction. This compund is the highest oxidizing agent of all the ROS. The level of $\mathrm{H}_{2} \mathrm{O}_{2}$ is controlled by a fine-tuned network enzymatic and non enzymatic antioxidants (low-weight molecule) that prevent the excess accumulation of $\mathrm{H}_{2} \mathrm{O}_{2}$ (Foyer and Noctor, 2005).

Cocoa has a mechanism for overcoming ROS

Table 3. Hydrogen Peroxide Content (ppb) in Three Scion Clones Material and Different Watering Interval

\begin{tabular}{lcccc}
\hline \multirow{2}{*}{ Clones } & \multicolumn{3}{c}{ Watering Intervals } & \multirow{2}{*}{ Mean } \\
\cline { 2 - 4 } & Two Days & Five Days & Eight Days & $23.88 \mathrm{~b}$ \\
\hline ICS 60 & 16.58 & 26.87 & 28.19 & $17.09 \mathrm{a}$ \\
KW 641 & 14.51 & 16.18 & 20.59 & $17.33 \mathrm{a}$ \\
Sulawesi 1 & 16.02 & 16.52 & 19.44 & $(-)$ \\
\hline Mean & $15.71 \mathrm{a}$ & $19.85 \mathrm{ab}$ & $22.74 \mathrm{~b}$ & \\
\hline
\end{tabular}

Note : Data in the same column or row followed by the same letters were not significantly different according to Tukey $5 \%$; Notation (-) shown there was no interaction between each factor. 
Table 4. Superoxide Dismutase Activity (unit $\mathrm{mg}^{-1}$ protein) in Three Scion Clones Material and Different Watering Interval

\begin{tabular}{lcccc}
\hline \multirow{2}{*}{ Clones } & \multicolumn{3}{c}{ Watering Intervals } & \multirow{2}{*}{ Mean } \\
\cline { 2 - 4 } & Two Days & Five Days & Eight Days & $3.16 \mathrm{~b}$ \\
\hline ICS 60 & 1.16 & 4.02 & 4.30 & $5.48 \mathrm{a}$ \\
KW 641 & 1.81 & 5.81 & 8.80 & $5.82 \mathrm{a}$ \\
\hline Sulawesi 1 & 1.86 & 6.51 & 9.08 & $(-)$ \\
\hline Mean & $1.61 \mathrm{~b}$ & $5.45 \mathrm{a}$ & $7.39 \mathrm{a}$ & \\
\hline
\end{tabular}

Note : Data in the same column or row followed by the same letters were not significantly different according to Tukey $5 \%$; Notation (-) shown there was no interaction between each factor; Data was transformed with

Table 5. Ascorbic Acid (mg AA g ${ }^{-1}$ ) in Three Scion Clones Material and Different Watering Interval

\begin{tabular}{lcccc}
\hline \multirow{2}{*}{ Clones } & \multicolumn{3}{c}{ Watering Intervals } & \multirow{2}{*}{ Mean } \\
\cline { 2 - 4 } & Two Days & Five Days & Eight Days & $1.09 \mathrm{~b}$ \\
\hline ICS 60 & 1.08 & 1.07 & 1.11 & $1.29 \mathrm{a}$ \\
KW 641 & 1.08 & 1.22 & 1.58 & $1.33 \mathrm{a}$ \\
Sulawesi 1 & 1.09 & 1.31 & 1.59 & $(-)$ \\
\hline Mean & $1.08 \mathrm{c}$ & $1.20 \mathrm{~b}$ & $1.43 \mathrm{a}$ & \\
\hline
\end{tabular}

Note : Data in the same column or row followed by the same letters were not significantly different according to Tukey $5 \%$; Notation (-) shown there was no interaction between each factor.

through antioxidant accumulation. Superoxide dismutase (SOD) is one of enzymatic antioxidants that contribute to reduce superoxide anion which very radical, either spontaneously or catalyzed reaction into oxygen and hydrogen peroxide $\left(\mathrm{H}_{2} \mathrm{O}_{2}\right)$ (Wang et al., 2018). Generally, SOD is an enzyme that had cofactor enzymes with micro-nutrients, such as Mn-SOD, Cu-SOD, and Fe-SOD. Alban et al. (2011) reported that cocoa has high activity of SOD enzyme to counteract ROS. SOD antioxidant can be seen based on its activity where the higher of its activity will higher to counteract the free radicals. Superoxide dismutase in plants can be seen based on its activity in units of protein weight. The higher superoxide activity will make the resistance of plant against to ROS also higher.

Table 4 informed that SOD activity was significantly influenced by each single factor of watering interval and clones. SOD activity increased in cocoa seedling that watered every 5 days and 8 days, compared to that watered every 2 days. According to that, drought stress caused the increasing of SOD activity. Otherwise, SOD activity of KW 641 and Sulawesi 1 clones were higher than ICS 60 clone. This condition was confirmed by the research of Alban et al. (2011), which showed that the tendency of a high activity of SOD in cocoa seedling was in line with drought stress severity.

Similar to SOD activity variable, ascorbic acid content was influenced by single factor of watering interval and single factor of clones (Table 5). Both KW 641 and
Sulawesi clones, respectively, it had value 1.29 mg. $\mathrm{g}^{-1}$ and $1.33 \mathrm{mg} . \mathrm{g}^{-1}$, were higher of ascorbic acid content than ICS 60 clone $\left(1.09\right.$ mg.g $\left.{ }^{-1}\right)$. Ascorbic acid content varies in watering interval treatment or in other words ascorbic acid of cocoa leaves is increasingly aligned with the drought stress level. Ascorbic acid in watering every 8 days $\left(1.08 \mathrm{mg} \cdot \mathrm{g}^{-1}\right)$ was very significantly different compared with watering every 5 day $\left(1.20 \mathrm{mg} \cdot \mathrm{g}^{-1}\right)$ and 2 days $\left(1.43 \mathrm{mg} \cdot \mathrm{g}^{-1}\right)$. Ascorbic acid in extreme drought stress (watering every 8 days) was increasing up to $10 \%$ compared with moderate stress condition (watering every 5 days) and $24.48 \%$ compared with adequate condition (regularly watering).

Ascorbic acid can neutralize ROS such as superoxide and hydrogen peroxide (Babu et al., 2013). Ascorbic acid has three main types of biological activities to reduce ROS i.e., as an enzyme cofactor, an antioxidant, and a donor or acceptor electron in chloroplast (Davey et al., 2002). Ascorbate acid is also as a substrate of ascorbate peroxidase enzyme (APX) (Lobo et al., 2010). Ascorbate peroxidases convert hydrogen peroxide to water and play a role as the antioxidant system (Caverzan et al., 2012). This enzyme is involved in the scavenging of hydrogen peroxide in ascorbate and glutathione pathways, and also utilizes ascorbic acid as the electron donor (Ahmad et al., 2010).

Tabel 6 demonstrated there were significant interaction of clones and watering intervals to total phenolic content. Total phenolic content of three 
Table 6. Phenolic Total (mg GAE g${ }^{-1}$ ) in Three Scion Clones Material and Different Watering Interval

\begin{tabular}{lcccc}
\hline \multirow{2}{*}{ Clones } & \multicolumn{3}{c}{ Watering Intervals } & \multirow{2}{*}{ Mean } \\
\cline { 2 - 4 } & Two Days & Five Days & Eight Days & 2.31 \\
\hline ICS 60 & $1.99 \mathrm{~b}$ & $2.10 \mathrm{~b}$ & $2.84 \mathrm{~b}$ & 3.91 \\
KW 641 & $2.06 \mathrm{~b}$ & $3.46 \mathrm{ab}$ & $6.22 \mathrm{a}$ & 3.59 \\
Sulawesi 1 & $2.12 \mathrm{~b}$ & $2.44 \mathrm{~b}$ & $6.21 \mathrm{a}$ & $(+)$ \\
\hline Mean & 2.06 & 2.67 & 5.09 & \\
\hline
\end{tabular}

Note : Data in the same column or row followed by the same letters were not significantly different according to Tukey $5 \%$; Notation $(+)$ showed there was an interaction between each factor.

Table 7. . Leaf Proline ( $\mu$ mol prolin $\left.\mathrm{g}^{-1}\right)$ in Three Scion Clones Material and Different Watering Interval

\begin{tabular}{lcccc}
\hline \multirow{2}{*}{ Clones } & \multicolumn{3}{c}{ Watering Intervals } & \multirow{2}{*}{ Mean } \\
\cline { 2 - 4 } & Two Days & Five Days & Eight Days & 10.60 \\
ICS 60 & $4.94 \mathrm{~d}$ & $8.52 \mathrm{bcd}$ & $18.32 \mathrm{~b}$ & 21.29 \\
KW 641 & $5.32 \mathrm{~cd}$ & $16.30 \mathrm{bc}$ & $42.24 \mathrm{a}$ & 17.02 \\
Sulawesi 1 & $8.17 \mathrm{bcd}$ & $10.71 \mathrm{bcd}$ & $32.18 \mathrm{a}$ & $(+)$ \\
\hline Mean & 6.14 & 11.85 & 30.91 & \\
\hline Note : Data in the same column or row followed by the same letters were not significantly different according to Tukey &
\end{tabular}

clones that watered every 2 days and 5 days showed no significantly different. In other hand, KW 641 and Sulawesi 1 that watered every 8 days had higher total phenolic content than ICS 60 clone. There were significant increment of total phenolic content of Sulawesi 1 and KW 641 that watered every 8 days compared with regularly watered. Total phenolic content of ICS 60 clone showed no significant different among of watering interval treatments.

Phenolic is a compound that highly contained in the cocoa plant. This phenolic group was characterized had one aromatic ring or $\mathrm{OH}^{-}$group. The activity of this compound was potential as antioxidant that can inhibit formation of hydroxyl free radical, superoxide anion, peroxyl radicals, alkyl radicals, singlet oxygen, and hydrogen peroxide (Foti, 2007). The phenolic compound can inhibit enzyme that had role to produce superoxide anion free radicals such as xanthine oxidase (Ryu et al., 2012). The phenolic compound is easily oxidized and used for enzymatic oxidation reactions of clutches as $\mathrm{H}$ donor substrate (AbdulHafeez et al., 2014). In another case, phenolic also contributes to other compound forming to protect plant from stress, such as lignin (Liu et al., 2018). The high phenolic content in plants is commonly related to the level of plant tolerance to abiotic stress (Varela et al., 2016).

Proline is an amino acid compound produced by plants and contribute to osmotic adjustment cell. In addition, proline also reported by Hayat et al. (2012) that it had potential as antioxidant that counteracts damaging from ROS. The producing of proline as secondary metabolite was caused by the occurrence of abiotic stress. The response from different condition to form proline was highly determined by plant genotype. The addition of proline through exogenous may be affecting in the enhancement of SOD enzyme activity, catalase, and peroxidase (Hayat et al., 2012). Rezaei-Chiyaneh (2018) reported that the positive correlations between antioxidant activity and proline accumulation indicate that antioxidant enzymes activity and osmoprotectant act on the target to minimize the adverse effects of oxidative stress caused by drought stress.

Result from the analysis of variance of proline content represented that watering intervals and clones had interaction effect to leaf proline content. Effect of watering intervals and clones to proline content in this trial was showed in Tabel 7. Leaf proline content in all clones that watered every 2 days showed no different each other. The same thing also demonstrated from seedlings that watered 5 days, where the proline content in all clones were not significantly different. Leaf proline content of all clones tested that watered 8 days significantly increased compared with watered regularly. It concluded that cocoa seedlings were more accumulating leaf proline in severe stress condition, compared with moderate drought stress and adequate water condition. Under severe drought stress, KW 641 and Sulawesi clones 1 had higher proline than ICS 60 clone. 


\section{CONCLUSIONS}

The increasing of drought stress severity would increase ROS of hydrogen peroxyde and then decrease leaf total chlorophyll content in cocoa grafting seedlings. Under drought stress, there was increment in the activities of antioxidant enzymes SOD and the content of non enzymatic antioxidant in form of ascorbic acid, total phenolic, and proline. Cocoa grafting seedlings with resistant scion clones, KW 641 and Sulawesi 1, showed less ROS of hydrogen peroxide, while, higher total chloropyll content, higher the activity of SOD enzymes, ascorbic acid, total phenolic, and proline than ICS 60 as succeptible scion clone. It was concluded that antioxidant properties could be a promising way for the early selection of cocoa genotypes tolerant to drought stress.

\section{REFERENCES}

Abdul-Hafeez, E. Y., N. S. Karamova, O. N. Ilinskaya. 2014. Antioxidant activity and total phenolic compound content of certain medicinal plants. International Journal of Biosciences, 5 (9), $213-222$.

Ahmad, P., C. A. Jaleel, M. A. Salem, G. Nabi, and S. Sharma. 2010. Roles of enzymatic and nonenzymatic antioxidants in plants during abiotic stress. Crit. Rev. Biotechnol., 30(3), 161-175.

Alban, M. K. A., S. E. Apshara, K.B. Hebbar,T. G. Mathias \& A. Sévérin. 2015. Potential of Antioxidant Enzymes in Depicting Drought Tolerance in Cocoa (Theobroma cacao L.) Genotypes at Young Age. African Journal of Science and Research, 4 (5) :18-23

Alban, M., K. A. amd S. E. A. K. B. Hebbar. 2016. Morpho-physiological Criteria for Assessment of Two Month Old Cocoa (Theobroma cacao L.) Genotypes for Drought Tolerance. Indian Journal Plant Physiology, 21(1), 23-30.

Alexieva, V., I. Sergiev, S. Mapelli \& E. Karanov. 2001. The effect of drought and ultraviolet radiation on growth and stress markers in pea and wheat. Plant, Cell and Environment, 24, 1337-1344.

Almeida, A. A. F. \& Valle, R. R. 2010. Cacao: ecophysiology of growth and production. In: MATTA, F. da (Ed.). Ecophysiology of tropical tree crops. New York: Nova Science Publishers. v.1, p.37-70.

Babu, D. P. Gurumurthy, S. K. Borra and K. M. Cherian. 2013. Antioxidant and free radical scavenging activity of triphala determined by using different in vitro models. Journal of Medicinal Plant Research, 7(39), pp. 28982905.

Bates , L.; R.P. Waldren \& R.P.I.D. Teare. 1973. Rapid determination of free proline for water stress studies. Plant and Soil, 39, pp. 205-207.

Caverzan, A., G. Passaia, S. B. Rosa, C. W. Ribeiro, F. Lazzarotto, and M. Margis-Pinheiro. 2012. Plant responses to stresses: Role of ascorbate peroxidase in the antioxidant protection. Genet. Mol Biol., 35(4), pp. 1011-1019.

Chéour, F., I. Kaddachi, D. Achouri, S. Bannour and L. Zorgui. 2014. Effects of water stress on relative water, chlorophylls and proline contents in barley (Hordeum vulgare L.) leaves. Journal of Agriculture and Veterinary Science, 7(6), pp. 13-16.

Davey, M. W., M. Van Montagu, and D. Inze. 2002. Ascorbate Metabolism and Stress. In : Inze, D. and Van Montagu, M., ed., Oxidative Stress in Plants, 1st ed. London: Taylor and Francis, pp. 333-363.

Foti, M. C. 2007. Antioxidant properties of phenols. Journal of Pharmacy and Pharmacology 2007, 59, pp. 1673-1685.

Foyer, C.H. and G. Noctor. 2005. Redox homeostasis and antioxidant signaling: A metabolic interface between stress perception and physiological responses. Plant Cell, 17, pp. 1866-1875.

Foyer, C. H. 2002. The Contribution of Photosynthetic Oxygen Metabolism to Oxidative Stress in Plants. In : Inze, D. and Van Montagu, M., ed., Oxidative Stress in Plants, 1st ed. London : Taylor and Francis, pp. 40-128.

Hayat, S.,Q., M. N. Alyemeni, A. S. Wani, J. Pichtel, \& A. Ahmad. 2012. Role of proline under changing environments. Plant Signal Behav. 7(11): 1456-1466.

ICCO. 2010. Impact of El Niño / La Niña Weather Events on The World Cocoa Economy. One hundred and forty-second meeting London, 13-17 September 2010.

ICCO. 2017. Production of Cocoa Beans. ICCO Quarterly Bulletin of Cocoa Statistic XLIII (3) : 1-2.

Liu, Q.,L. Luo, and L. Zheng. 2018. Lignins: Biosynthesis and Biological Functions in Plants. Int J Mol Sci., 19(2), 335.

Lobo, V., A. Patil, A. Phatak, and N. Chandra. 2010. Free radicals, antioxidants and functional foods: Impact on human health. Pharmacogn Rev. 4(8): 118-126.

Maheshwari, R. and R. S. Dubey. 2009. Nickel-induced oxidative stress and the role of antioxidant defence in rice seedlings. Plant Growth 
Regulation, 59(1), pp. 37-49.

Marklund, S., Marklund, G. (1974). Involvement of the superoxyde anion radical in the auto oxidation of pyrogallol and a convenient assay for superoxyde dismutase. Eurupian Journal of Biochemistry, 47, 469-474.

Ming-yi J., W. Yang, J. Xu, and Q. Chen. 1994. Active oxygen damage effect of chlorophyll degradation in rice seedlings under osmotic stress. Acta Botanica Sinica 36 (4 ) 289 - 295.

Rezaei-Chiyaneh, E., S. M. Seyyedi, E. Ebrahimian, S. S. Moghaddam, and C. A. Damalas. 2018. Exogenous application of gamma-aminobutyric acid (GABA) alleviates the effect of water deficit stress in black cumin (Nigella sativa L.). Industrial Crops \& Products, 112, pp. 741-748.

Ryu, H. W., J. H. Lee, J. E. Kang, Y. M. Jin, and K. H. Park. 2012. Inhibition of Xanthine Oxidase by Phenolic Phytochemicals from Broussonetia papyrifera. Journal of Korean Soc. Appl. Biol. Chem., 55, pp. 587-594.

Sade, B., S. Soylu, and E. Soylu. 2011. Drought and oxidative stress. African Journal of Biotechnology 10,54 , pp. $102-109$.

Saglam, A., N. Saruhan, R. Terzi, and A. Kadioglu. 2011. The Relations between Antioxidant Enzymes and Chlorophyll Fluorescence Parameters in Common Bean Cultivars Differing in Sensitivity to Drought Stress. Russian Journal of Plant Physiology, 58(1), pp. 60-68.

Sakiroh, I. Sobari, \& M. Herman. 2015. Teknologi mengurangi dampak perubahan iklim pada kakao di lahan kering. Sirinov, 3(2), pp. $55-$ 66.

Santos, I. C., A. F. Almeida, D. Anhert, A. S. Conceciao, C. P. Pirovani, J. L. Pires, R. R. Valle, \& V. C. Balligar. 2014. Molecular, Physiological and Biochemical Responses of Theobroma cacao L. Genotypes to Soil Water Deficit. PLoS ONE, 9(12), pp. $1-31$.

Shevyakova, N. I., E. A. Bakulina, and V. Kuznetsov. 2009. Proline antioxidant role in the common ice plant subjected to salinity and paraquat treatment inducing oxidative stress. Russian Journal of Plant Physiology, 56(5), pp. 663669.
Sudarmadji, S. 2010. Analisa Bahan Makanan dan Pertanian. Yogyakarta: Penerbit Liberty.

Susilo, A. W. 2015 a. KW 641, klon harapan kakao tahan kering. Warta Pusat Penelitian Kopi dan Kakao Indonesia, 27(3) : 1-5.

Soertani, S. \& Soenardjan.1984. Pengalaman dalam musim kemarau panjang 1982 di PT. Perkebunan XVIII. Perkebunan Indonesia. 19-28.

Taga, M.S., E.E. Miller and D.E. Pratt. 1984. Chia seeds as a source of natural lipid antioxidants. J. Am. Oil Chem. Soc. 61:928-931

Upadhyaya, H., M. H. Khan, and S. K. Panda. 2007. Hydrogen Peroxide Induces Oxidative Stress in Detached Leaves of Oryza Sativa L. Gen. Appl. Plant Physiology, 33(2), pp. 83 - 95.

Varela, M. C., I. Arslan, M. A. Reginato, A. M. Cenzano, M. V. Luna. 2016. Phenolic compounds as indicators of drought resistance in shrubs from Patagonian shrublands (Argentina). Plant Physiology and Biochemistry, 104, pp. $81-$ 91.

Wang, Y., R. Branicky, A. Noë, and S. Hekim. 2018. Superoxide dismutases: Dual roles in controlling ROS damage and regulating ROS signaling. J. Cell Biol., 217(6), pp.1915-1928.

Winaryo, A. Iswanto, dan H. Winarno. 1997. Kajian Penggunaan Tegangan Osmotik dan Kerapatan Stomata sebagai Kriteria Seleksi Klon Kakao Tahan Cekaman Air. Pelita Perkebunan 13(2): 63-70.

Zakariyya, F., B. Setiyawan, and A. W. Susilo. 2016. Stomatal, Proline, and Leaf Water Status Characters of Some Cocoa Clones (Theobroma cacao L.) on Prolonged Dry Season. Pelita Perkebunan 33 (1), pp. 109-117.

Zanneti, L. V., C. R. D. Milanez, V. N. Gama, M. A. G. Aguilar, C. A. S. Souza, E. Campostrini, T. M. Ferraz, \& F. A. M. M. A. Figueiredo. 2016. Leaf application of silicon in young cacao plants subjected to water deficit. Pesq. agropec. bras., 51(3), pp. 215-223. 